\title{
The URban poetry of Valerit Briusov
}

Cassio de Oliveira'

Resumo: Este artigo é dedicado a uma análise da figura do eu-lírico e dos vários motivos usados nos ciclos de poemas urbanos do simbolista russo Valeii Briusov. A fascinação de Briusov com temas urbanos relaciona-se com seu interesse pela poesia do francês Charles Baudelaire e do belga Emile Verharen, que lhe providenciaram exemplos, respectivamente, do eu-lírico moderno e do uso do tema da modernidade na poesia simbolista. No entanto, a poesia de Briusov se distingue daquela de Baudelaire pela presença mais marcante, explícita e moderna de um conjunto de imagens estritamente relacionadas ao ambiente da cidade; sua poesia também se distingúe da de Verhaeren pela criação de um eu-lírico consideravelmente mais variado, complexo e dotado do olhar inerente à modernidade. Ainda que Briusov tenha sido influenciado por esses poetas na criação de seus poemas urbanos, é evidente que seus poemas revelam traços característicos da concepção estética - e, pode-se dizer também, ética - de seu autor, figura singular na formação do movimento simbolista na Rússia. Assim sendo, este artigo também propõe uma forma de integração de um gênero especial da poesia de Briusov no contexto de sua criação lírica em geral.

Palavras-chave: Simbolismo russo, modernidade, poesia urbana.

In a March 1899 letter to Ivan Bunin (1870-1953), Valerii Briusov (18731924) wrote:

Вы не любите городской весны, а моим раздумьям она ближе, чем грязь в деревне и голые сучья обеснеженного леса. Мы малю наблюдаем

1 Yale University, New Haven, CT, USA. 
город, мы в нем только живем и почему-то называем природой только дорожки в саду, словно не природа камни тротуаров, узкие дали улиц и светлое небо с очертаньями крыш. (LITERATURNOE NASLEDSTVO, 1973, p. 441; also quoted in GROSSMAN, 1985, pp. 208-9)²

Primarily in two cycles of poems published in the volumes Tertia Vigilia (1900) and Urbi et.Orbi (1903), as well as in individual poems throughout his career, Briusov manifested his fascination with urban life and modernity, following the themes explored by two authors who exerted major influence on his work, the Frenchman Charles Baudelaire (1821-1867) and the Belgian Emile Verhaeren (1855-1916). Although he was not the first to turn the city into a subject for poetry in Russia (Nikolai Nekrasov most notably had done so before him), Briusov developed a specific image of the modern city that was unprecedented in Russian poetry. Furthermore, Briusov may very well have been responsible for the introduction of the theme of the flâneur in Russian poetry. In Briusov's poems the "urban sights and sounds are refracted through the sensibility of a brooding, whimsical stroller who prefers night to day" (GROSSMAN, 1985, p. 240). In the creation of this strolling lyric self, Briusov shows his indebtedness to Baudelaire, whose persona of the flâneur became a marker of the advent of modernity in Western Europe.

To what extent, however, should Briusov's flâneur be seen as just a rip-off of Baudelaire's character? To what extent does he develop a distinct lyric self that takes a different direction in the exploration of the city, and in a way reveals surprising facets of the flâneur that even Baudelaire had not explored? If, as so many critics and readers of his work tend to believe, Briusov "seemingly developed no truly distinctive voice to ring in the ears of generations of readers" (GROSSMAN, 1985, p. 12), then how important in fact is his development of

2 "You don't love the spring in the city, but it is closer to my thoughts than the dirt on trees and the naked boughs of the forest after the snow has melted. We do not observe the city much, we only live in it and for some reason call nature only the little pathway in the garden, as if the stones in the sidewalk, the wide expanses of streets and the bright sky with the outline of the roofs were not nature." All translations are mine, except where indicated. 
urban themes in these cycles? One is reminded of Iurii Tynianov's description of Briusov's poetry:

Если мы остановимся на вопросе, что нового, что своеобразного в Брюсове как литературном явлении, нам вовсе не вспомнится одна какаялибо вещь, одна какая-либо до конца характерная для него особенность, ему одному свойственный оборот стиха, интонация, с ним неразрывно связанная. ${ }^{3}$ (TYNIANOV, 1967, p. 522)

Is Briusov really a poet whose main characteristic is being stylistically unremarkable?

The first aim of the present article is to demonstrate why the answer to the question above might be "no". We shall turn to Briusov's urban cycles, which are arguably his most important poetic works if taken as a whole, in which the lyric self is in fact one of the most memorable of the many distinctive voices that Briusov cultivated throughout his career. We shall start by emphasizing the common roots of Briusov's and Baudelaire's flâneurs, as well as the influence of Verhaeren's poetry on these cycles in particular. However, we also intend to show that the city depicted in these poems is essentially different from the Paris of Baudelaire and the cities in Verhaeren's poems: if anything, Briusov's merit lies in the creation of an imagery of the city that is at once more modern and explicit than Baudelaire's, and of a lyric self at once more memorable and modern than Verhaeren's. Briusov may be said therefore to have defined the figure of the flâneur as a phenomenon of modernity in ways that had not occurred before (pace Nekrasov's advocates) in Russian poetry and literature.

Baudelaire's influence on Briusov was arguably among the most important in the formation of his poetic persona. As Wanner writes, "Unlike Balmont, Bryusov always had a keen interest in French literature", starting in his youth, so that in 1895 "Baudelaire was the most prominent member in Bryusov's

3 "If we focus on the matter of what is new, what is peculiar in Briusov as a literary event, we are not reminded in general of anything, of any special feature characteristic of Briusov, of any poetic turn of phrase inherent to him, of any intonation indelibly associated with him." 
poetical partheom, togethet with Vetlaine and Tyutchev" (WANNFR, 1905. 7. 82). However. Wannet does not ascign the urthan ponetics of Briusov to an explicitly Baudelatean Irend; instead, he regatds the "cult of death" and "morbid eroticism", as well as the "view of woman as a demonic temptress" and the "reptesentation of lowemaking as a form of sadomasochist forture" (WANNTR, 1996, p.83) as the specific traits of Bavdelaire's aesthetics that left their mark in Briusov. Indeed Baudclate's influcnce was manifested as early as in the poems Briusor wrote in his youth. publshed in 1894 and 1895 in the three volumes of Russkis smmolusty Some of the poems are clearly inspired by the "demonic" strain of poetry that infected Symbolist poets all over the world. and which can be ascribed ditectly fo Baudelaite's intluence as pointed out by Wannet. However, if is known that Briusov also acknowledged the importance of Baudelaite in creating poctry of specifically urban character; in his notes to Frantsustac litik $X 7 X$ acha, publishod in 1909. he wrote: "Baudelare was one of the first to create the poetry of the modern city. the poetry of modern life.

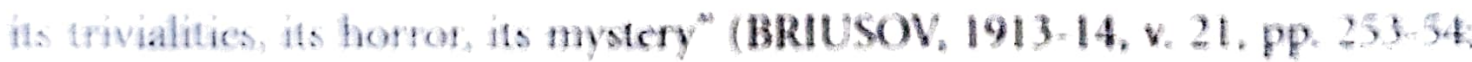
quoted in translation in WANNIR, $1990, \mathrm{p}, 88$ ).

The year 1895 also saw the composituon of onc of Briumov's most famous

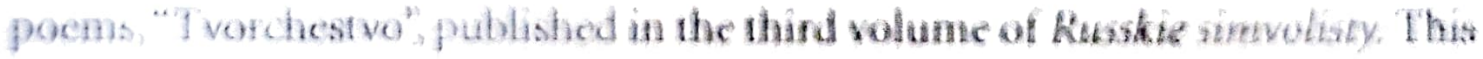
poen may show signs of the influence of Raudelaies urban peetery the

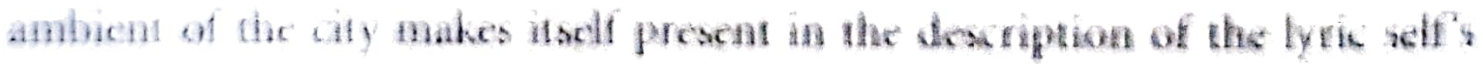

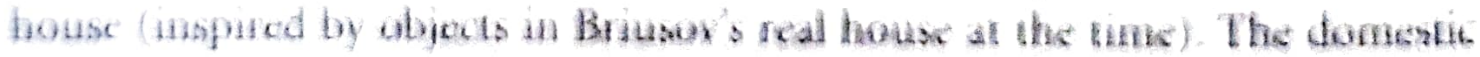

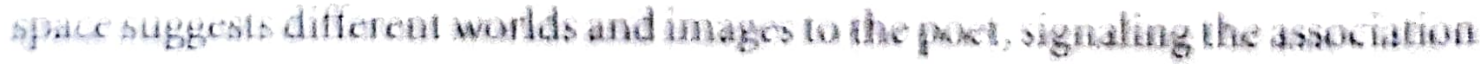

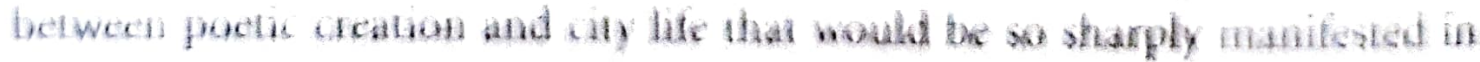

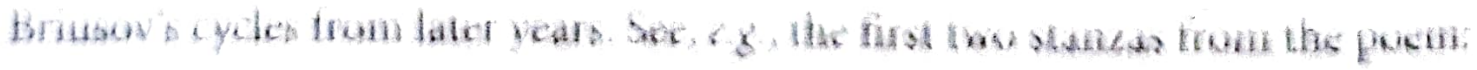

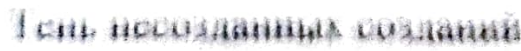

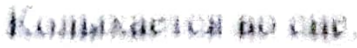

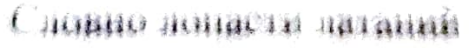

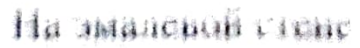

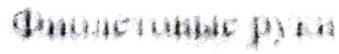

Ha shasenoh thone 
Полусонно чертят звуки

В звонко-звучной тишине.` (BRIUSOV, 1961, р. 70)

As Grossman writes, "A decade later, Khodasevich cited this poem as a prime example of creation of a fantasy-world from the everyday environment" (GROSSMAN, 1985, p. 44). In his memoir of Briusov, Khodasevich would praise, not without some irony, the pungency contained in his early poetry, in "All that tropical fantasy - on the banks of the Yauza, the trans-evaluation of all values - in the Sretenka district of Moscow" (KHODASEVICH, 1980, 150). Nowhere is this "trans-evaluation of all values" manifested more sharply than in this poem, in which from the leaves of a domestic palm tree by the wall of the poet's apartment the "shadow of uncreated creations" manifests itself, transforming those same leaves into "violet hands" which, in a synesthesia typical of the early excesses of Decadence and Symbolism, "sketch sounds/In a ringing-sonorous silence". Later in the poem, Briusovinserts two contradictory images associated to the moon: first, "prozrachnye kioski" grow "Pri lazarevoi lune", only to be followed by the lines "Vskhodit mesiats obnazhennyi/Pri lazarevoi lune..." (BRIUSOV, 1961, p. 70). According to Briusov's wife, this azure moon was a large lamp outside a circus located across the street from Briusov's house on Tsvetnoi bul'var in Moscow (BRIUSOV, 1961, p. 718). The reference to multiple sources of light - that is, to an artificial light mirroring the moonlight - can also be read as an evocation of the following lines from Baudelaire's poem "Paysage", the first in the cycle "Tableaux Parisiens" in Les Fleurs du Mal:

Il est doux, à travers les brumes, de voir nâtre

Létoile dans l'azur, la lampe à la fenêtre,

Les fleuves de charbon monter au firmament

Et la lune verser son pâle enchantement. (BAUDALAIRE, 1990, p. 115; my emphas is C.d.O.)

1 "The shadow of uncreated aeations/Huttes during step// ike the blade of palm trees/On the enameled wall.//Violet hands/On the enane wall/Hatf askep sketch sounds/ln a tinging - oonorous silence." 
Interestingly enough, this same poem, tresides inferlucing the cucle on Paris, is dedicated to deactibing the act of prowical creation, the same subiect of Brusav's poem, as wedl as a conctant theme in hrs lafer oufput. "Paysage begins with the lines "le veux, pout composet chastement mes églogues / Coucher aupres du ciel comme les astrologues (17bid. P. 115) and much of it consists of a pratse of the whiters powet to create poetry out of the elements of everyday life in Paris, culminating with the capacity to "tirer un soleil de mon coeur. et de fare/T) mes pensers brolants une ticde atmosphere (thid. p. 116). The poet a capacity to create a "tepid atmosphete" out of his "butning thoughts" although this expression contains something of an anticlimax - is mitrored, in "T vorchestwo", by the way the domestic space reproduces and is inhabited by the poet's dreams, we in the last stanza:

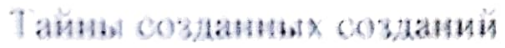

( )аской ластите ко мuc,

11 трененет теи, латаний

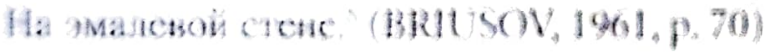

The "shadow" (6e") of the uncreated creations in the first stantabecomes the "secfets" (qamy) of the creations that are finally lulfilled in the last when (in the poem as a finshed work). These screts are indirealy compared agan to the quivering shadow of the palm ree on the wall, sa that the poetic creation, caflief a pure product of the anconsoious as bivity of the mind (xet the first stanka "Wolyhactsid to snc"), once materidierd, is retlected in the shadow on the wall.

In this poen, in Briusors descripuon of mutriple svents taking phike

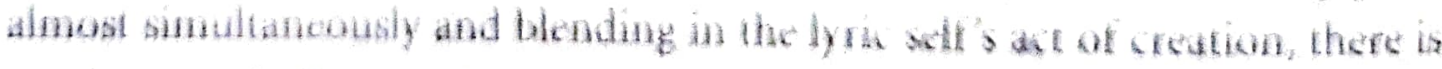

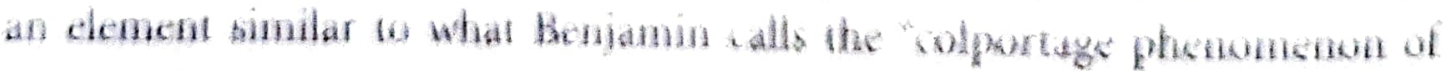

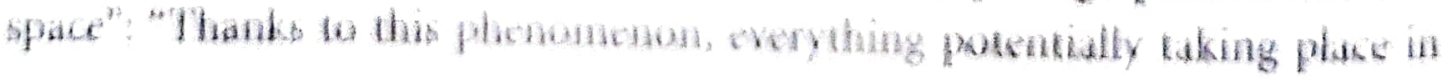

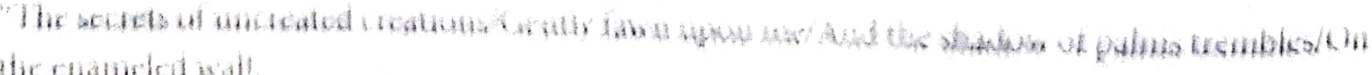


this one single room is perceived simulaneously" (BFNIAMIN, 1999, p. 418). This phenomenon is suggestive of an ethical-aesthefic dimension to Briusov's poctry: to him, poctry is "made up of insights into the universe caught through the window of the poct's soul at moments when the soul's nonrational powers were at their poak" (GROSSMAN, 1985, p. 16). It is the pole of the artist, therefore, to establish a connection between reality and the poet's inner soul, or art itself, which to him ultimately amount to one and the same thing.

In a sociological analysis which is yet useful to the present argument. Walter Benjamin would associate the creation of a private space inherent to modernity with the rise of a correspondent "phantasmagoria of the interior". in the 1935 expose to his unfinished Arcades Project:

For the private individual, the place of dwelling is for the first time oppesed to the place of work. The former constitutes itself as the interior... The private individual, who in the office has to deal with reality, needs the domestic interior 10 sustain him in his illusions.... In the formation of his private environment, both /commercial and social considerations/ are kept out. From this arise the phantasmagorias of the interior which, for the private man, represents the universe. In the interior, he brings logether the far away and the long age. His living room is a box in the theater of the world. (BENIAMIN, 1994, p9, 8.

Nowhere is the notion of the interior space as a place where other times and spaces converge expressed more clearly as in " $\mathrm{My}$ k iarkim krakam ac privykli.." one of the poems of the gyte "V stenakh" published in Fertia Vigitia (covering the years 1897-1901). The last wo lines of the poem go ts

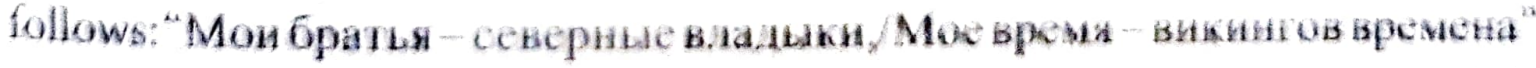
(BKUUSOV, 1961, p. 135). This is a likely reterence the sarly years of the existence of an organized sate in medieval kas; when a tymaty destended

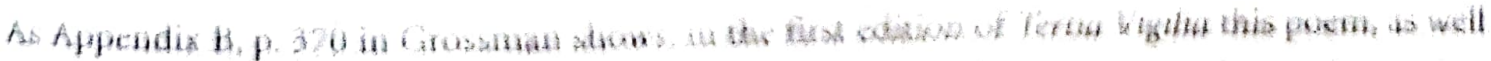

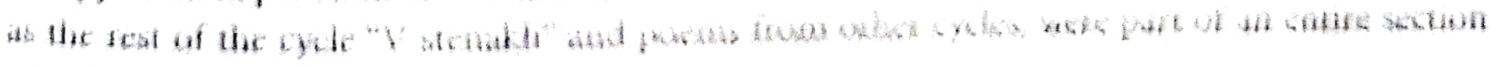
Lalled atmply" Gurud?

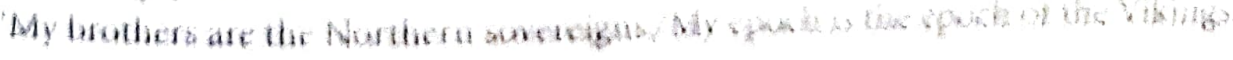


from the Varangians (a Viking group) ruled over Novgorod and neighboring regions. However, all this yearning for past times and places takes place, not in a place where such an evocation of history would be most expected, but rather in the lyric self's own home, as the second stanza (out of three) shows:

\author{
Мы дышим комнатною пылью, \\ Живем среди картин и книг, \\ И дорог нашему бессилью \\ Отдельный стих, отдельный миг. ${ }^{8}$ (Ibid., p. 135)
}

The lyric self then experiences the yearning for other worlds as a result of his weakness or limitations. "As artist he shares, perhaps more than he wishes, the spiritual limitations of his breed and his time. For him walls are not always barriers. They can also be shelter from immensity, from the glare of infinity, and as such, they inspire affection" (GROSSMAN, 1985, p. 210). At the same time that they provide shelter from the outer world, as the stanza above shows, they also provide the means for the lyric self's own overcoming of his weaknesses, by enclosing in them the books and images that he needs in order to create his own parallel worlds.

The walls in the name of the cycle do not enclose only private spaces, but public ones as well. E.g., in the poem "Ia liubliu bol'shie doma..." the second stanza goes as follows:

\author{
Пространства люблю площадей, \\ Стенами кругом огражденные, \\ В час, когда еше нет фонарей, \\ А залеплились звезды смущенные." (BRIUSOV, 1961, р. 132)
}

8 "We breathe the dust from the room/We live anong paintings and books/And the separate element, the separate moment/ds dear lo our powertessness."

9 "I love the space of squares,/Guarded all around by walls - / At the hour, when there are no streetlights yel, /But the cmbarrassed stars already began to glow." 
The squares mentioned in this stanza play the role of a liminal space, belonging at once to the lyric self's intimate world and to the public space of the city. The liminal character is further reinforced by the time of the day, after sunset but before the street lamps are turned on. In this enclosed darkness, faintly lit by the glow of the stars, the poet conceals his own songs, and yet experiences a mysterious harmony or consonance with the city noises:

Город и камни люблю,

Грохот его и шумы певучие, -

В миг, когда песню глубоко таю,

Но в восторге слышу созвучия. ${ }^{10}$ (Ibid., p. 133)

This harmony seized upon by the lyric self is expressed in the poem by the rhyme pevuchie/sozvuchiia, which emphasizes the ambiguous, nebulous character of the sounds coming from the street. This is not the first rhyme in the poem that suggests a certain ambiguous and mysterious harmony bringing various elements together; one of the pairs in the first stanza of the poem, goroda/kholodom, likewise does not match perfectly. However, whereas in the first pair of rhymes there is something akin to a subdued sound (-om) following an ascending sound (the ending in -a), in the last stanza the last word sounds more affirmative than the first word in the pair: to the ending -chie, with the two vowels showing relatively little contrast, follows the ending -chiia, with the rising diphthong -iia.

Grossman (1985, p. 211) in fact does not translate "sozvuchiia" as "harmony", but rather as "rhyme", emphasizing the theme of poetic creation of this poem. Reading the word as "rhyme" creates an interesting contrast between the formal aspect of the rhyming pair and the semantic aspect of the word, stressing at the same time the irrational power of creation, which generates a not so evident rhyme even when the lyric self voluntarily "conceals" his song deep in his soul.

10 "I love the city and the stones, /its din and the singing murmurs - At the moment when I hide deep the song/But, enraptured, I hear the harmony." 
Notice aloo how the three stanzas that constitute the poem form a progression towards cver smallet units of time: the first stanza has the expression "V Ani", whereas the second has "V chas" and the third has "V mig." On the othet hand, in tems of space the poem presents a succession of contrasting dimensions, creating a kind of asymmetric picture of the city: in the first stanza. the pairs "bol'shic doma" and "uzkie ulitsy" are opposed; in the second stanza, the paits "prostranstva ploshchadei" and "prostranstva krugom ograzhdennvic stenamin that is, the maximally open spaces of the squares and the enclosed spaces of rooms in houses. In the third stanza, the contrast is the mast extreme within the confines of the city: the lyric self loves the city and the stones of which it is made, he loves both its loud noises and its singing murmurs. Altogether this poem presents a flecting, highly aestheticized and concise image of the city by means of a small number of poetic images.

The personality of Briusov's flaneur is exposed with particular sharpness in the following untitled poem from this cycle:

Лкоблю вечериии свет, и первыс опии.

И1 небо бленное, 1де звезд ене ие видо.

Как странен взор подей в медитепьной тени,

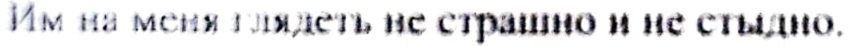

И я с јнднми как брат, и все иронано им,

Heчs

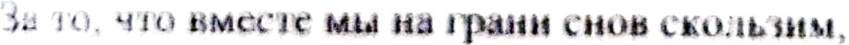

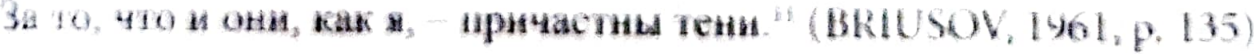

On the emergence of public lighting on the streets of Paris under Napoleon 111, Benjamin writes in "Le Paris du second empire chez Baudelaire" the

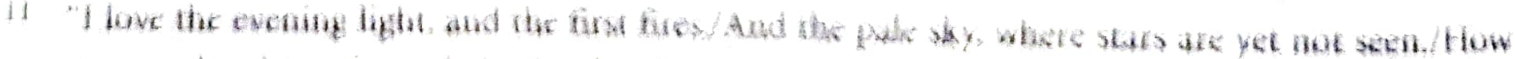

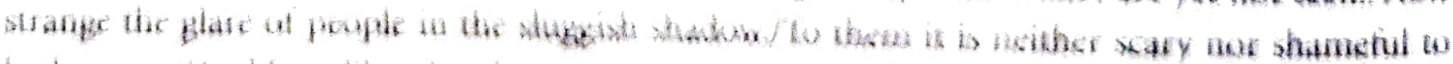

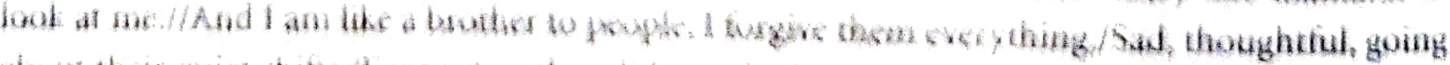

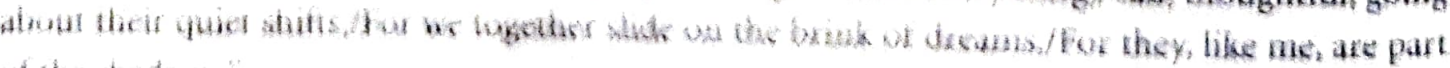
af the aliadiand 
following: "This way of increasing safety in the city made the crowds feel at home even at night, and removed the starry sky from the ambience of the big city more effectively than tall buildings had ever done... The moon and the stars are no longer worth mentioning" (BENJAMIN, 2003, p. 28). This light that even blocks the glow of the stars, that makes them unnoticeable at night, allows the flâneur to integrate with the crowd he is watching, albeit the crowd itself, in this poem, is partly hidden in the shadows - in fact, as the last line of the poem shows, both the crowds and the lyric self belong to the shadows. This fits in with Benjamin's description of the "dialectic of flânerie": "on one side, the man who feels himself viewed by all and sundry as a true suspect and, on the other side, the man who is utterly undiscoverable, the hidden man" (BENJAMIN, 1999, p. 420). The shadows and the night in Baudelaire, in fact, have a connotation related to crime and prostitution, as in the first stanza of "Le Crépuscule du Soir," part of the "Tableaux parisiens":

Voici le soir charmant, ami du criminel;

Il vient comme un complice, à pas de loup; le ciel

Se ferme lentement comme une grande alcôve,

Et l'homme impatient se change en bête fauve. (BAUDELAIRE, 1996, p. 129)

The night is thus an environment propitious for the man's change into a "ferocious beast". The night of modernity, with its artificial lighting that brings safety to all passers-by, allows both for the enlightened ideal of the panorama, of the complete visibility of everything and everybody ("Im na menia gliadet' ne strashno i ne stydno"), and also for the Romantic ideal of night as the opposite of day, as the moment when man manifests his innermost nature ("Et l'homme impatient se change en bête fauve"). It is simultaneously a space for intimacy (the sky that resembles an alcove) and for darkness, and yet it is a space where all the "participants of the shadow" see each other and join in a kind of brotherhood, recognizing their common nature.

In a poem from 1910, Briusov would bring up again the motif of electrical lights, this time reinforcing their moralistic aspect, their clarity and objectivity as opposed presumably to candle lights or other more unstable forms of 


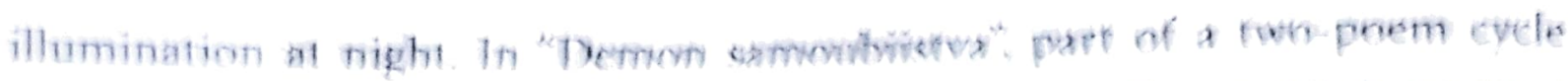

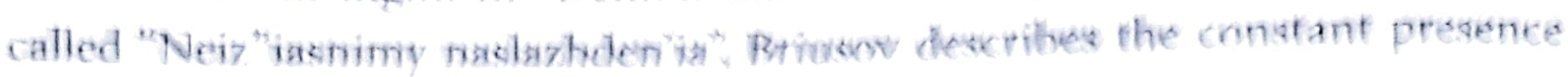

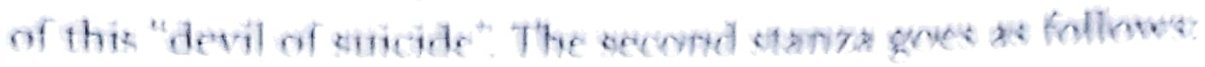

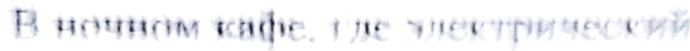

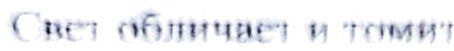

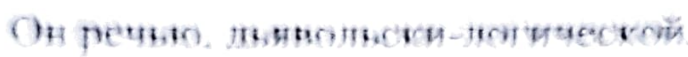

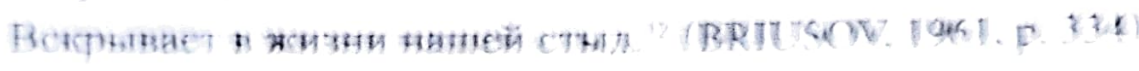

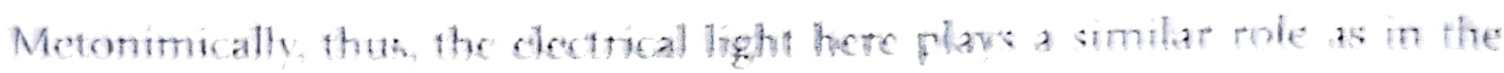
poem analyzed in the provous pagen ac it diuminates the ate where the exchange

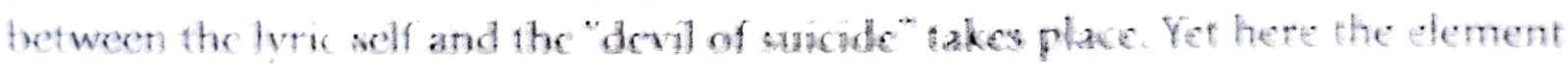

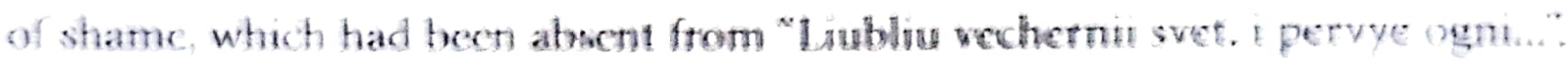
is revealed by the devil in his "logical-demonical" talk. The light that had allowert the tyrical self to reveal himself and commune with his "brethren" in the experience of the cify at night in the previons procum. here butdens and condems him and makes thm susceptible to the dralls loghal afgumetres.

Whereas in this poem Briuson attempts. and to a ictuin extent succeeds in incomporating two Baudclaifcat themes - that of the ofty and that of

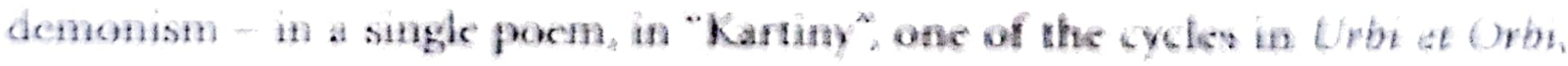

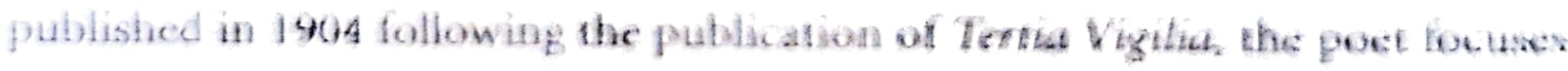

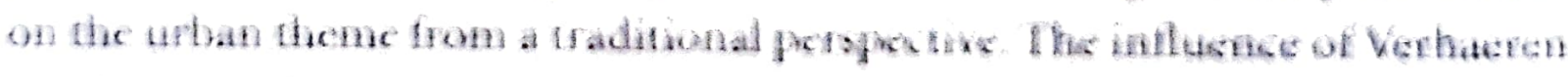

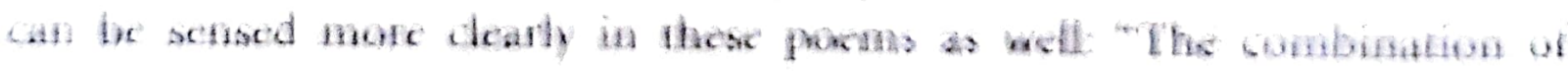

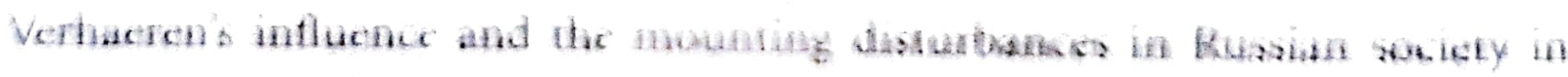

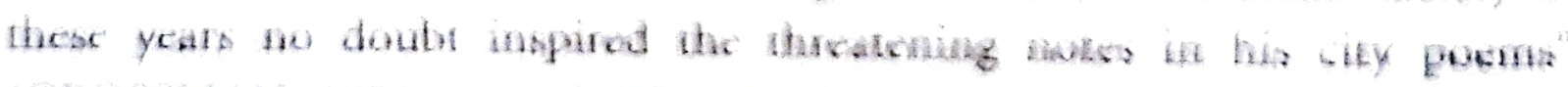

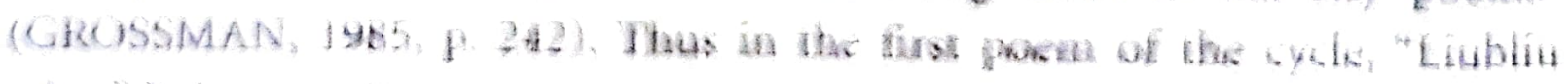
adno thriaten whes:

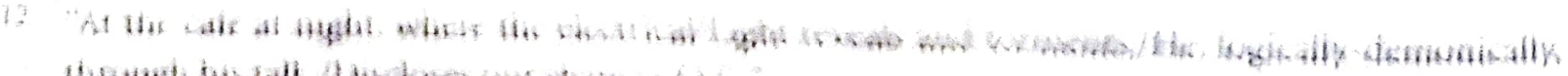

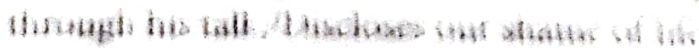


Смотрн в лицо идуших мимо.

В их тайны властно увлсчсн.

То полон грустью нелюдимой.

То богомолен. то влюблен. ${ }^{3}$ (BRIUSOV, 1961, p. 211)

One notices therefore the change in tone in the crowds that the lyric self faces in his walks. Whereas he regarded these crowds as his brethren in poems from "V stenakh", here they become more like strangers, guardians of secrets that the lyric self is able to read in their faces, but with whom he does not communicate so intimately. Here also the lyric self assumes more and more the persona of the fláncur, as in the first stanza:

\section{Люблю одно: бродить без цели \\ По шумным улицам, один; \\ Люблю часы святых безделий, \\ Часы раздумий и картин. ${ }^{14}$ (Ibid., p. 211)}

As Benjamin writes, "Basic to flanerie, among other things, is the idea that the fruits of idleness are more precious than the fruits of labor. The flatreur, as is well known, makes "studies"” (BENJAMIN, 1999, p. 453). Britusov's lyric self embodies perfectly this characteristic of the flaneur: he cherishes his moments of idleness, and the fruits of his observation of the world - the "pictures" of "scenes" that the cycle's title refers to - are comparable to the "studies" made by Benjamin's flaneur. To Briusov, the flaneur, more than a character of modernity, was virtually a new model for his poetic persona. This becomes more evident, eg. in his appreciation of Verhaeren's poetry, which was fundamental to Briusov's poetic maturation: "Verhaeren confirmed Bryusov's feeting that the poet's soul offered a much more powerful kns than his predecrosars had

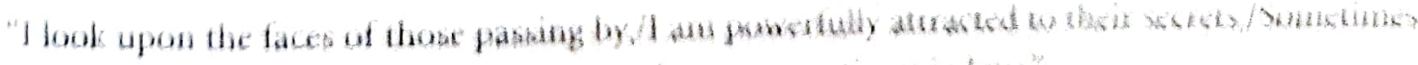

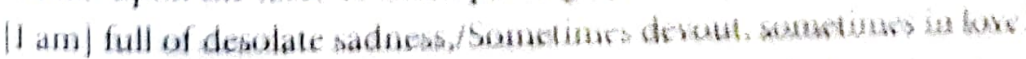

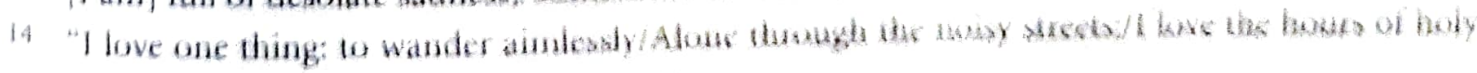
idleness, /fours of reflection and sertios.
} 
thought: anvthing in the wotld might lye visible theough it" (C.ROSSMAN. 1985, P. 308). This notion can lye ditectly ascribed on Bandelaire, ex. in Io Splecn de Parts, in the text "Tes Tonles": "Te preete joulf de cet incomparable privilege quil peut à sa gube dre lui-méme ef autrui. Comme ces àmes crtantes qui herchent un cotps, il entte, quand il veut, dans le personnage de chacun. Pout lui seul, tout est vacant; et si de cerfaines places paraissent lut dtre fermés. cert qua ses yeux clles ne valent pas la peine d'étre visitées" (BAUDELAIRE, $1998, \mathrm{P} .45$ ). The metaphor of the poet as a soul that can cnter any body at will is at the hean of Briusov's multiple poetic personat. and is likewise present in his identification with the crowds in various poems of his urban cycles.

The slight change in tone that can be perceived in "Kartiny". on the other hand, has been related to Briusov's acquaintance with Verhaeren. In one of Briusov's translations of Verhacten, the poem "London" (whose translation is dated November 29, 1903-August 18, 1905. a couple of years after the latest poems in "Kartiny"), death is perceived in the crowd wandering through london, among the typical characters of decadent poetry that acquirt a character of social critique in Verhaeren:

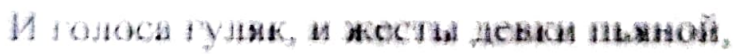

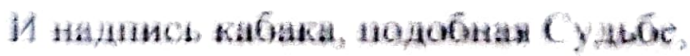

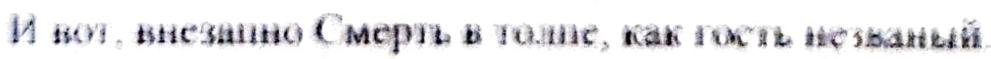

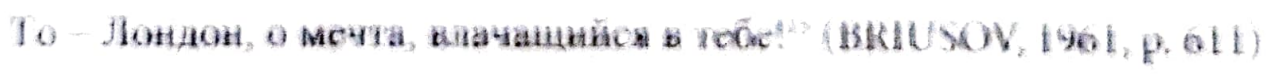

The presence of death or of any oher theatenang element in the crowd is indecd something that had not boen suggested in "V alenakh" Briusov's previous urban cycle, allowgh it would resonate in Demon amonabistva"

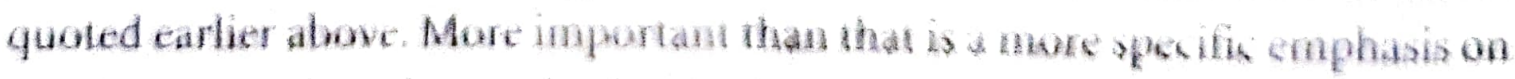

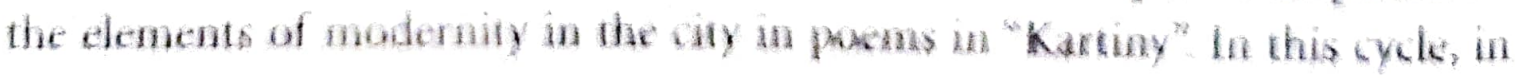

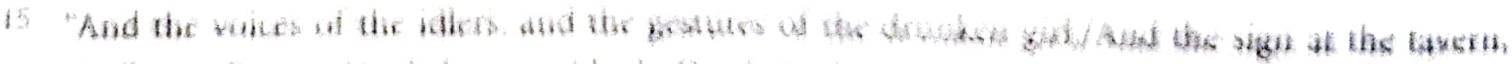

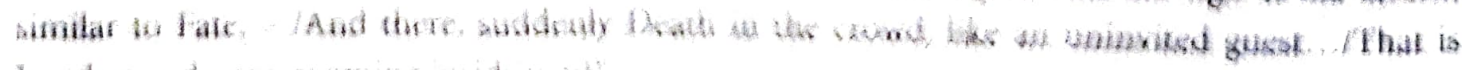

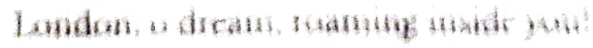


fact, one has the impression that the world outside the lyric self acquires more prominence. It is not only the suggestion of a mythical urban night or sunset that generates the creative process of the poem; its creation depends on a more physical reality, although still shrouded in the lyric self's personal perception of it. This may or may not be related to Verhaeren's poetry, but it is interesting to notice, $\mathcal{C} . g .$, the following stanza in "London":

Вокзалов едкий дым, где светится мерцаньем,

Серебряным огнем, скорбь газовых рожков,

Где чудища тоски ревут по расписаньям

Под беспощадный бой Вестминстерских часов. ${ }^{16}$ (Ibid., pp. 610-1)

And to compare it with the following three last stanzas from "Noch" (dated September 1902), one of the poems in "Kartiny":

Стрелой вонзаясь в города,

Свистя в полях, гремя над бездной,

Летят немолчно поезда

Вперед по полосе железной.

Глядят несытые ряды

Фабричных окон в темный холод,

Не тихнет резкий стон руды,

Ему в ответ хохочет молот.

И, спину яростно клоня,

Скрывают бешенство проклятий

Среди железа и огня

Давно испытанные рати." (Ibid., р. 216)

16 "The caustic smoke of the train stations, where glows in a shimmer, With a silver tlame, the sorrow of gas jets, /Where the monsters of emmi roar on schedule/At the merciless chime of the West minster clock."

17 "Piercing the cities like an arrow, Whizaing through the fields, thundeting over the abyss/trains incessantly fly/Ahead on the iron suip./The hungry rows/Of factory windows state in the dark 
The tones of the two poems are distinctly different, and yet they both approach elements of modernity - the trains at the station, the factories by the train line - in similar ways, that is, from a critical stance in relation to the mechanization of life. Briusov in fact would remain somewhat ambiguous, oscillating between a praise of modernity and an occasional criticism of it. Although Grossman claims that it would entail "the building of barricades in the streets of Moscow in 1905 to evoke from Bryusov anything to compare with the revolutionary spirit of Verhaeren" (1985, p. 242), here it is possible to notice already an emphasis on mechanical or inanimate elements (the iron ore, the hammer, the rows of factory windows, the dehumanized hordes of workers) that acquire something of a life of their own, like the "monsters of melancholy" ("bêtes d'ennui" in the original) that roar at regular intervals at the London train station.

The presence of these inanimate but enlivened elements in Briusov's poetry, noticeable already in a poem such as "Tvorchestvo," points to the presence of that fundamental characteristic of the modern lyric self, the spleen. As Benjamin writes in his 1939 exposé, Baudelaire

recognizes in spleen the latest transfiguration of the ideal; the ideal seems to him the first expression of spleen....The linchpin of his entire theory of art is "modern beauty", and for him the proof of modernity seems to be this: it is marked with the fatality of being one day antiquity, and it reveals this to whoever witnesses its birth. Here we meet the quintessence of the unforeseen, which for Baudelaire is an inalienable quality of the beautiful. The face of modernity itself blasts us with its immemorial gaze. (BENJAMIN, 1999, pp. 22-3)

Looking back, after an entire century, to the poems of Briusov, isn't it possible to recognize this drive for "modern beauty" in the same use, as the subject matter for their poetry, of a modernity that was vanishing at every

cold,/The sharp moan of the ore does not die down,/The hammer laughs in response to him.// And, vehemently bending their back,/The hordes, having long ago passed the test,/Hide the fury
of curses/Among iron and fire." 
minute, constantly evolving into an ever more modern age? In a way Briusov believes that there is no theme that a writer cannot turn into matter for poetry: to him, Beauty may or may not be present in reality, but it is always imposed on this reality through the poct's creative power at the moment of the poetic creation. Thus, in Briusov's flaneur it is possible to perceive the attempt to integrate the present world into poetry, to find the dimension of the ideal in the spleen - in the "toska", in the melancholy of modern times. Some of Briusov's attempts to endow his subject matter with a sense of instantaneity were more successful than others, but they all can be said to have been fruitful, in the sense that they influenced a whole generation of Russian poets in the twentieth century that transformed the urban landscape into an ever more refined object of poetic investigation.

\section{Bibliography}

BAUDELAIRE, Charles. Les Fleurs du Mal: édition de 1861. Paris: Gallimard, 1996. Le Spleen de Paris. Petits poèmes en prose. Paris: Le Livre de Poche, 1998. BENJAMIN, Walter. "The Paris of the Second Empire in Baudelaire." In: BENIAMIN, Walter. Selected Writings, Volume 4. 1938-1940. Howard Eiland and Michael W. Jennings, eds. Cambridge, MA: The Belknap Press of Harvard University Press, $2003.3-92$.

The Arcades Project. Translated by Howard Eiland and Kevin McLaughlin; prepared on the basis of the German volume edited by Rold Tiedemann. Cambridge, MA: The Belknap Press of Harvard University P'ress, 1999.

BRIUSOV, Valerii. Polnoe sobramie sochinenii i perevodov. Vol. 21. St. Petersburg: Sirin, $1913-14$.

Stikhotvoreniia i Poemi. Leningrad: Sovetskii pisatel', $1 \% 61$.

GROSSMAN, Joan Delaney. Valery Brywsov and the Riddle of Kusian Deadence. Berkeley, Los Angeles: Universily of California Press, 1985.

KHODASEVICH, V. I. "IIOM 'Bryusov". The Diary of Vakery Bryusov (1893-1905),

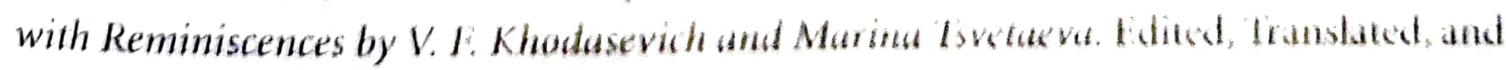
with an Introductory Essay by foan Delaney Cinosman. Berkeley, Los Angeles: University of California Press, 1980. 
Literaturnoe nasledstvo. Ivan Bunin, Kniga pervaia. Vol. 84:1. Moskva: Nauka, 1973. TYNIANOV, Iurii. "Valerii Briusov". Arkhaisty $i$ novatory. München: Wilhelm Fink Verlag, 1967. 521-40.

WANNER, Adrian. Baudelaire in Russia. Gainesville, FL: University Press of Florida, 1996. 